Brief report

\title{
Suicide ideation across reproductive life cycle of women Results from a European epidemiological study
}

\author{
Judith Usall $^{\mathrm{a}, *}$, Alejandra Pinto-Meza ${ }^{\mathrm{a}, \mathrm{b}}$, Anna Fernández ${ }^{\mathrm{a}, \mathrm{b}}$, Ron de Graaf ${ }^{\mathrm{c}}$, Koen Demyttenaere ${ }^{\mathrm{d}}$, \\ Jordi Alonso $^{\mathrm{e}}$, Giovanni de Girolamo ${ }^{\mathrm{f}}$, Jean Pierre Lepine ${ }^{\mathrm{g}}$, Viviane Kovess ${ }^{\mathrm{h}}$, Josep Maria Haro ${ }^{\mathrm{a}}$ \\ a Sant Joan de Déu-SSM, Fundació Sant Joan de Déu, Instituto de Salud Carlos III, Centro de Investigación en Red de Salud Mental (CIBERSAM), Spain \\ ${ }^{\mathrm{b}}$ Red de Investigación en actividades preventivas y promoción de la salud en Atención Primaria (RedIAPP, Instituto de Salud Carlos III RD06/0018/0017), Spain \\ ${ }^{c}$ Netherlands Institute of Mental Health and Addiction, The Netherlands \\ d University Hospital Gasthuisberg, Belgium \\ e Health Services Research Unit, Institut Municipal d'Investigació Mèdica (IMIM-Hospital del Mar), Barcelona, Spain \\ ${ }^{\mathrm{f}}$ Health Care Research Agency, Emilia-Romagna Region, Bologna, Italy \\ g Hôpital Fernand Widal, Assistance Publique Hôpitaux de Paris, INSERM U 705 CNRS UMR 7157, University Paris Diderot, Paris, France \\ ${ }^{\mathrm{h}}$ MGEN Foundation for Public Health, University of Paris Descartes, EA 4069, Paris, France
}

\section{A R T I C L E I N F O}

\section{Article history:}

Received 25 August 2008

Received in revised form 1 December 2008

Accepted 1 December 2008

Available online 19 January 2009

\section{Keywords:}

Suicide ideation

Reproductive life cycle

Perimenopause

\begin{abstract}
A B S T R A C T
Background: The aim of the present study is to compare suicide ideation among women in the pre-, peri-, and post-menopause using a cross-sectional household survey of non-institutionalised adults from six European countries.

Methods: In total, 8794 out of 21,425 respondents provided data for the following study. To use men as a comparison group, we defined three different groups of male subjects, based on the mean age of the women groups.

Results: We found an increased risk of suicide ideation among women in their peri-menopause compared with women in their pre- or post-menopause and men. This finding was independent of mood and anxiety disorders.

Limitations: Some categories showed few individuals. The cross-sectional design of our study does not allow us to conclude causal relationship between variables.

Conclusion: The occurrence of suicide ideation varies across the reproductive life cycle of women. (c) 2008 Elsevier B.V. All rights reserved.
\end{abstract}

\section{Introduction}

The study of the relationship between mood disorders and reproductive life cycle of women is relevant. Despite controversies, it seems that women reproductive phases (i.e. pre, peri and post-menopause) have an effect on the frequency, presentation, and course of mood disorders (Cohen, 2003), and that the perimenopause phase is one of special risk for developing depression (Prior, 1998; Soares, 2008). Besides, there are associations between premenstrual

\footnotetext{
* Corresponding author. Sant Joan de Déu-SSM, Fundació Sant Joan de Déu, Centro de Investigación Biomédica en Red de Salud Mental (CIBERSAM)C/ Antoni Pujades, 4208830 Sant Boi Barcelona, Spain. Tel.: +34 936406350x2356.

E-mail address: jusall@sjd-ssm.com (J. Usall).
}

disphoric disorder and lifetime experience of depression (APA, 1994). Thus, these findings suggest that gonadal hormone level fluctuations across reproductive cycle could partially explain such effects (Freeman et al., 2004).

Suicide is probably the most negative outcome of depression. Some data seems to point out that there could be a relationship between menstrual cycle and suicidal ideation, being it more common in those phases of the menstrual cycle when oestrogen levels are low (Saunders and Hawton, 2006). However, to date, we have not found the data regarding the relationship between women reproductive life cycle and suicidal ideation.

The aim of the present study is to compare suicide ideation among women in the pre-, peri-, and post-menopause in a large epidemiological European sample. 


\section{Methods}

\subsection{Sample}

Cross-sectional household survey of non-institutionalised adults (18 years or older) from Belgium, France, Germany, Italy, the Netherlands, and Spain. In total, 21,425 respondents provided data between January 2001 and August 2003.

For optimising the length of the interview, two main questionnaire itineraries were defined. Women of the present study answered the long interview (containing questions about menstrual periods). The long interview included all respondents who endorsed the screening questions for mental disorders (high risk for mental disorders group) plus a random $25 \%$ of low risk individuals. Men followed the same path. After listwise deletion, there was a total of 4918 women and 3689 men with complete data for the present study. A detailed description of sampling and methods has been previously published (Alonso et al., 2004).

Table 1

Sociodemographic and clinical characteristics of the sample and presence of suicide ideation.

\begin{tabular}{|c|c|c|c|c|c|c|}
\hline & \multicolumn{3}{|l|}{ Women } & \multicolumn{3}{|l|}{ Men } \\
\hline & Pre-menopause & Peri-menopause & Post-menopause & $18-45$ years old & 46-57 years old & 58 years and older \\
\hline$\%(n)$ & $\begin{array}{l}57.3 \% \\
(2787)\end{array}$ & $\begin{array}{l}2.0 \% \\
(118)\end{array}$ & $\begin{array}{l}40.7 \% \\
(2013)\end{array}$ & $\begin{array}{l}53.2 \% \\
(1833)\end{array}$ & $\begin{array}{l}19.5 \% \\
(796)\end{array}$ & $\begin{array}{l}27.2 \% \\
(1060)\end{array}$ \\
\hline Mean age (SD) & $\begin{array}{l}35.62 \\
(9.22)\end{array}$ & $\begin{array}{l}50.42 \\
(6.60)\end{array}$ & $\begin{array}{l}63.67 \\
(10.48)\end{array}$ & $\begin{array}{l}32.99 \\
(7.56)\end{array}$ & $\begin{array}{l}51.38 \\
(3.37)\end{array}$ & $\begin{array}{l}68.68 \\
(4.79)\end{array}$ \\
\hline \multicolumn{7}{|l|}{ 12-month mental disorders \% ( $n$ ) } \\
\hline No 12-month mental disorders & $\begin{array}{l}84.78 \% \\
(2112)\end{array}$ & $\begin{array}{l}81.39 \% \\
(88)\end{array}$ & $\begin{array}{l}41.54 \% \\
(1561)\end{array}$ & $\begin{array}{l}92.00 \% \\
(1554)\end{array}$ & $\begin{array}{l}92.42 \% \\
(685)\end{array}$ & $\begin{array}{l}95.54 \% \\
\text { (959) }\end{array}$ \\
\hline Only 12 -month mood disorders & $\begin{array}{l}3.27 \% \\
(230)\end{array}$ & $\begin{array}{l}4.16 \% \\
(10)\end{array}$ & $\begin{array}{l}3.36 \% \\
(164)\end{array}$ & $\begin{array}{l}2.48 \% \\
(109)\end{array}$ & $\begin{array}{l}1.74 \% \\
(38)\end{array}$ & $\begin{array}{l}1.9 \% \\
(56)\end{array}$ \\
\hline Only 12 -month anxiety disorders & $\begin{array}{l}9.05 \% \\
(286)\end{array}$ & $\begin{array}{l}10.12 \% \\
(12)\end{array}$ & $\begin{array}{l}7.24 \% \\
(185)\end{array}$ & $\begin{array}{l}4.56 \% \\
(120)\end{array}$ & $\begin{array}{l}4.17 \% \\
(49)\end{array}$ & $\begin{array}{l}2.35 \% \\
(35)\end{array}$ \\
\hline $\begin{array}{l}\text { 12-month comorbid mood and } \\
\text { anxiety disorders }\end{array}$ & $\begin{array}{l}2.9 \% \\
(159)\end{array}$ & $\begin{array}{l}4.34 \% \\
(8)\end{array}$ & $\begin{array}{l}2.02 \% \\
(103)\end{array}$ & $\begin{array}{l}0.96 \% \\
(50)\end{array}$ & $\begin{array}{l}1.67 \% \\
(24)\end{array}$ & $\begin{array}{l}0.21 \% \\
(10)\end{array}$ \\
\hline \multicolumn{7}{|l|}{ Marital status \% ( $n$ ) } \\
\hline Married & $\begin{array}{l}66.1 \% \\
(1851)\end{array}$ & $\begin{array}{l}80.7 \% \\
(88)\end{array}$ & $\begin{array}{l}65.2 \% \\
(1231)\end{array}$ & $\begin{array}{l}53.4 \% \\
(1038)\end{array}$ & $\begin{array}{l}83.6 \% \\
(613)\end{array}$ & $\begin{array}{l}84.4 \% \\
(853)\end{array}$ \\
\hline Previously married & $\begin{array}{l}5.4 \% \\
(254)\end{array}$ & $\begin{array}{l}13.2 \% \\
(24)\end{array}$ & $\begin{array}{l}28.6 \% \\
(657)\end{array}$ & $\begin{array}{l}3.3 \% \\
(84)\end{array}$ & $\begin{array}{l}8.0 \% \\
(105)\end{array}$ & $\begin{array}{l}10.8 \% \\
(150)\end{array}$ \\
\hline Never married & $\begin{array}{l}28.4 \% \\
(688)\end{array}$ & $\begin{array}{l}6.1 \% \\
(6)\end{array}$ & $\begin{array}{l}6.2 \% \\
(125)\end{array}$ & $\begin{array}{l}43.3 \% \\
(711)\end{array}$ & $\begin{array}{l}8.4 \% \\
(78)\end{array}$ & $\begin{array}{l}4.8 \% \\
(57)\end{array}$ \\
\hline \multicolumn{7}{|l|}{ Number of children \% ( $n$ ) } \\
\hline Without children & $\begin{array}{l}39.1 \% \\
(979)\end{array}$ & $\begin{array}{l}12.5 \% \\
(13)\end{array}$ & $\begin{array}{l}12.1 \% \\
(236)\end{array}$ & $\begin{array}{l}57.1 \% \\
(961)\end{array}$ & $\begin{array}{l}13.3 \% \\
(127)\end{array}$ & $\begin{array}{l}13.6 \% \\
(149)\end{array}$ \\
\hline One child & $\begin{array}{l}19.1 \% \\
(575)\end{array}$ & $\begin{array}{l}16.0 \% \\
(21)\end{array}$ & $\begin{array}{l}18.3 \% \\
(336)\end{array}$ & $\begin{array}{l}14.6 \% \\
(301)\end{array}$ & $\begin{array}{l}18.4 \% \\
(146)\end{array}$ & $\begin{array}{l}18.5 \% \\
(169)\end{array}$ \\
\hline 2 o more children & $\begin{array}{l}41.8 \% \\
(1233)\end{array}$ & $\begin{array}{l}71.6 \% \\
(84)\end{array}$ & $\begin{array}{l}69.6 \% \\
(1439)\end{array}$ & $\begin{array}{l}28.4 \% \\
(568)\end{array}$ & $\begin{array}{l}68.3 \% \\
(523)\end{array}$ & $\begin{array}{l}67.8 \% \\
(738)\end{array}$ \\
\hline \multicolumn{7}{|l|}{ Employment status \% ( $n$ ) } \\
\hline Working & $\begin{array}{l}70.3 \% \\
(1931)\end{array}$ & $\begin{array}{l}55.8 \% \\
(65)\end{array}$ & $\begin{array}{l}20.7 \% \\
(470)\end{array}$ & $\begin{array}{l}81.2 \% \\
(1546)\end{array}$ & $\begin{array}{l}87.5 \% \\
(651)\end{array}$ & $\begin{array}{l}17.4 \% \\
(157)\end{array}$ \\
\hline Homemaker & $\begin{array}{l}15.7 \% \\
(459)\end{array}$ & $\begin{array}{l}21.7 \% \\
(31)\end{array}$ & $\begin{array}{l}20.0 \% \\
(458)\end{array}$ & $\begin{array}{l}003 \% \\
(5)\end{array}$ & $\begin{array}{l}0.1 \% \\
(2)\end{array}$ & $\begin{array}{l}0.1 \% \\
(2)\end{array}$ \\
\hline $\begin{array}{l}\text { Not working } \\
\text { (student, retired, sick leave) }\end{array}$ & $\begin{array}{l}14.0 \% \\
(403)\end{array}$ & $\begin{array}{l}22.5 \% \\
(22)\end{array}$ & $\begin{array}{l}59.3 \% \\
(1085)\end{array}$ & $\begin{array}{l}18.6 \% \\
(282)\end{array}$ & $\begin{array}{l}12.4 \% \\
(143)\end{array}$ & $\begin{array}{l}82.4 \% \\
(901)\end{array}$ \\
\hline \multicolumn{7}{|l|}{ Country $\%(n)$} \\
\hline Belgium & $\begin{array}{l}3.8 \% \\
(319)\end{array}$ & $\begin{array}{l}2.22 \% \\
(11)\end{array}$ & $\begin{array}{l}3.9 \% \\
(224)\end{array}$ & $\begin{array}{l}3.89 \% \\
(234)\end{array}$ & $\begin{array}{l}3.36 \% \\
(104)\end{array}$ & $\begin{array}{l}3.93 \% \\
(128)\end{array}$ \\
\hline France & $\begin{array}{l}21.74 \% \\
(487)\end{array}$ & $\begin{array}{l}26.71 \% \\
(21)\end{array}$ & $\begin{array}{l}18.75 \% \\
(315)\end{array}$ & $\begin{array}{l}20.73 \% \\
(326)\end{array}$ & $\begin{array}{l}21.77 \% \\
(140)\end{array}$ & $\begin{array}{l}18.61 \% \\
(118)\end{array}$ \\
\hline Germany & $\begin{array}{l}29.48 \% \\
(405)\end{array}$ & $\begin{array}{l}35.28 \% \\
(26)\end{array}$ & $\begin{array}{l}32.66 \% \\
(293)\end{array}$ & $\begin{array}{l}31.07 \% \\
(274)\end{array}$ & $\begin{array}{l}27.73 \% \\
(110)\end{array}$ & $\begin{array}{l}35.25 \% \\
(177)\end{array}$ \\
\hline Italy & $\begin{array}{l}22.38 \% \\
(552)\end{array}$ & $\begin{array}{l}10.94 \% \\
(15)\end{array}$ & $\begin{array}{l}23.78 \% \\
(362)\end{array}$ & $\begin{array}{l}21.31 \% \\
(399)\end{array}$ & $\begin{array}{l}25.61 \% \\
(190)\end{array}$ & $\begin{array}{l}21.95 \% \\
(220)\end{array}$ \\
\hline The Netherlands & $\begin{array}{l}6.56 \% \\
(370)\end{array}$ & $\begin{array}{l}5.13 \% \\
(13)\end{array}$ & $\begin{array}{l}5.99 \% \\
(256)\end{array}$ & $\begin{array}{l}6.49 \% \\
(209)\end{array}$ & $\begin{array}{l}6.7 \% \\
(117)\end{array}$ & $\begin{array}{l}5.36 \% \\
(124)\end{array}$ \\
\hline Spain & $\begin{array}{l}16.04 \% \\
(654)\end{array}$ & $\begin{array}{l}19.71 \% \\
(32)\end{array}$ & $\begin{array}{l}14.92 \% \\
(563)\end{array}$ & $\begin{array}{l}16.5 \% \\
(391)\end{array}$ & $\begin{array}{l}14.83 \% \\
(135)\end{array}$ & $\begin{array}{l}14.91 \% \\
(293)\end{array}$ \\
\hline Presence of suicide ideation \% (n) & $\begin{array}{l}1.1 \% \\
(64)\end{array}$ & $\begin{array}{l}7.8 \% \\
(7)\end{array}$ & $\begin{array}{l}1.0 \% \\
(27)\end{array}$ & $\begin{array}{l}0.8 \% \\
(34)\end{array}$ & $\begin{array}{l}1.0 \% \\
(19)\end{array}$ & $\begin{array}{l}0.6 \% \\
(6)\end{array}$ \\
\hline
\end{tabular}


The design of the study and data collection process were approved by ethical boards of all participating institutions.

\subsection{Measures}

Women who reported they still had menstrual periods or whose periods stopped temporarily because of birth control, pregnancy, diet, or extreme exercise, were considered as being in their pre-menopause. Women who stopped having periods temporarily because of possible start of menopause or whose periods stopped permanently but had passed less than one year since the last menstrual period, were considered as being in their peri-menopause. Finally, women who stopped having menstrual periods permanently for more than one year were coded as being in the post-menopause.

In order to compare women to men, we created three different groups of male subjects, considering each women group mean age plus one standard deviation and using unweighted data. Male groups were as follows: 1) those between 18 and 45 years old (mean age of pre-menopause women was 35.62 years old, $S D=9.22$ ); 2) those between 46 and 57 years old (mean age of peri-menopause women was 50.42 years old, $S D=6.60$ ); and 3 ) those from 58 years and older (mean age of post-menopause women was 63.67 years old, $\mathrm{SD}=10.48$ ).

Respondents were asked about suicide ideation during the previous 12-months. The specific question was: "Have you seriously thought about committing suicide during the last 12-months? (Yes/No)".

The presence of a 12-month mood disorder (major depression episode, dysthymic disorder) and anxiety disorder (social phobia, specific phobia, generalised anxiety disorder, agoraphobia and panic disorder) was evaluated with version 3.0 of the World Health Organization's (WHO) Composite International Diagnostic Interview (CIDI 3.0), developed and adapted by the WHO to be used in the WHO-World Mental Health Survey Initiative (Kessler and Ustun, 2004). 12-month mental disorders were combined in order to create four categories: no mental disorders, only mood disorders, only anxiety disorders, and comorbid mood and anxiety disorders.

\subsection{Statistical analyses}

We report prevalence of suicide ideation for women and for each "comparison" age-group of men.

Logistic regression analyses were performed to estimate the association of suicide ideation and reproductive cycle in women (using the "comparison" group for men when analysing data regarding men), adjusting by mental disorder categories and socio-demographics (marital status, number of children, and employment status). The logistic regression model carried out with the women's sample was also adjusted by age. Collinearity between age and reproductive cycle was tested using the VIF index ( VIF = 3.46). As VIF value was under 10 , we assumed that these variables were not collinear.

Data were weighted to adjust for differences in the probability of selection of respondents within households, differential non-response, to adjust for residual differences between sample and country population, and to account for the different questionnaire itineraries.
Table 2

Prevalence of suicide ideation across reproductive cycle in women by mental disorder category.

\begin{tabular}{clll}
\hline & Pre-menopause & Peri-menopause & Post-menopause \\
\hline No mental disorder & $0.52 \%$ & $8.22 \%$ & $0.56 \%$ \\
& $(11)$ & $(4)$ & $(8)$ \\
Only 12-month & $5.88 \%$ & $14.16 \%$ & $4.08 \%$ \\
mood disorders & $(17)$ & $(2)$ & $(7)$ \\
Only 12-month & $1.43 \%$ & 0 & $0.88 \%$ \\
anxiety disorders & $(7)$ & & $(4)$ \\
12-month comorbid & $13.01 \%$ & $12.57 \%$ & $13.57 \%$ \\
mood and anxiety & $(29)$ & $(1)$ & $(8)$ \\
disorders & & & \\
\hline
\end{tabular}

Statistical analyses were carried out using the Stata Software 9.2 .

\section{Results}

Peri-menopausal women showed seven times higher prevalence of suicide ideation (7.8\%) than the other groups $(1.1 \%$ for pre-menopause and $1.0 \%$ for post-menopause; $p=0.004$ ) (Table 1). The prevalence of suicide ideation for men was very similar among groups (between $0.6 \%$ in the older group and $1.0 \%$ for those aged between 46 and 57 years; $p=0.77$ ).

Table 2 shows the prevalence of suicide ideation across reproductive cycle in women by mental disorder category. Compared to pre and post-menopausal women without mental disorders, women in their peri-menopause showed higher prevalence of suicide ideation.

The association of suicide ideation with peri-menopause was significant after adjusting by mental disorders and sociodemographics $(\mathrm{OR}=9.01 ; 95 \% \mathrm{CI} 1.88-43.26$ compared to premenopausal women; OR $=6.67 ; 95 \% \mathrm{CI}$ 1.34-33.25 compared to post-menopausal women). On the other hand, the oldest men showed a decreased odds for presenting suicide ideation ( $\mathrm{OR}=0.0295 \% \mathrm{Cl} 0.01-0.73$ ). The presence of only mood disorders or comorbid mood and anxiety disorders was associated to an increased probability of suicide ideation both, in men and women (data not shown but available upon request). By contrast, the presence of only anxiety disorders did not show any significant association.

Interaction between reproductive cycle and mental disorders in women was not statistically significant.

\section{Discussion}

The results of the present study should be interpreted in the context of the following limitations. First, some categories showed very few individuals. Second, menopausal status was assessed by means of participants' self report, and no hormone level analyses were considered. Third, the crosssectional design of our study does not allow us to conclude causal relationship between variables. Fourth, we do not know if there are country differences regarding reproductive cycle and suicide ideation since appropriate comparisons among countries were not possible due to limited sample size.

Despite the above limitations, results show that there is an increased risk of suicide ideation among women in their perimenopause compared with women in their pre or postmenopause. This finding was independent of mood and anxiety disorders. 
The association between peri-menopause and increased suicide ideation could be partially explained by the relation between oestrogens and serotonin. There is evidence suggesting that oestrogens enhance serotonergic activity (Halbreich et al., 1999). Low serotonergic function appears to increase suicide risk in those with predisposing factors (BacaGarcia et al., 2003; Mann, 1998). In the peri-menopause period, especially at an early stage, there is an intense fluctuation in serum levels of gonadal steroids. The "oestrogen withdrawal theory" proposes that the onset or worsening of mood symptoms in peri-menopausal women result from an abrupt hypoestrogenic state. This does not occur during the menopause when hormone levels become more stable (Genazzani et al., 2005). Such fluctuation could also explain the increased suicide ideation regardless depressive symptoms. However, this should be considered as an speculation since we could not derive this conclusion from our results.

Similar to previous work (Bernal et al., 2007), we found that the presence of 12-month mood and comorbid mood and anxiety disorders was associated to suicide ideation.

Among sociodemographic variables, we found that the oldest men (58 years and older) showed a reduced risk of suicide ideation. It has been suggested that different age cohorts show variable rates of suicidal thoughts and behaviours, and that rates of suicidal ideation decrease with age (Fairweather et al., 2007).

To conclude, this is the first European epidemiological study evaluating the relationship between women reproductive life cycle and suicidal ideation. Our results highlight the importance of women reproductive cycle on it. Special attention should be paid to women in their peri-menopause since they are at an increased risk for suicide ideation.

\section{Role of funding source}

The ESEMeD project is funded by the European Commission (Contracts QLG5-1999-01042; SANCO 2004123), the Piedmont Region (Italy), Fondo de Investigación Sanitaria, Instituto de Salud Carlos III, Spain (FIS 00/0028), Ministerio de Ciencia y Tecnología, Spain (SAF 2000-158-CE), Departament de Salut, Generalitat de Catalunya, Spain, Instituto de Salud Carlos III (CIBER CB06/02/0046, CIBER SALUD MENTAL), and other local agencies and by an unrestricted educational grant from GlaxoSmithKline.

\section{Conflict of interest}

We have no conflict of interest.

\section{Acknowledgements}

The ESEMeD project is funded by the European Commission (Contracts QLG5-1999-01042; SANCO 2004123), the Piedmont Region (Italy), Fondo de Investigación Sanitaria, Instituto de Salud Carlos III, Spain (FIS 00/0028), Ministerio de Ciencia y Tecnología, Spain (SAF 2000-158-CE), Departament de Salut, Generalitat de Catalunya, Spain, Instituto de Salud Carlos III (CIBER CB06/02/0046, CIBER SALUD MEN$\mathrm{TAL}$ ), and other local agencies and by an unrestricted educational grant from GlaxoSmithKline.
The surveys discussed in this article were carried out in conjunction with the World Health Organization World Mental Health (WMH) Survey Initiative. We thank the WMH staff for assistance with instrumentation, fieldwork, and data analysis. These activities were supported by the United States National Institute of Mental Health (R01MH070884), the John D. and Catherine T. MacArthur Foundation, the Pfizer Foundation, the US Public Health Service (R13-MH066849, R01-MH069864, and R01 DA016558), the Fogarty International Center (FIRCA R01TW006481), the Pan American Health Organization, Eli Lilly and Company, Ortho-McNeil Pharmaceutical, Inc., GlaxoSmithKline, and Bristol-Myers Squibb. A complete list of WMH publications can be found at http://www.hcp.med.harvard. edu/wmh/.

\section{References}

Alonso, J., Angermeyer, M.C., Bernert, S., Bruffaerts, R., Brugha, T.S., Bryson, H., de Girolamo, G., Graaf, R., Demyttenaere, K., Gasquet, I., Haro, J.M., Katz, S.J., Kessler, R.C., Kovess, V., Lépine, J.P., Ormel, J., Polidori, G., Russo, L.J., Vilagut, G., Almansa, J., Arbabzadeh-Bouchez, S., Autonell, J., Bernal, M., BuistBouwman, M.A., Codony, M., Domingo-Salvany, A., Ferrer, M., Joo, S.S., Martínez-Alonso, M., Matschinger, H., Mazzi, F., Morgan, Z., Morosini, P., Palacín, C., Romera, B., Taub, N., Vollebergh, W.A., ESEMeD/MHEDEA 2000 Investigators, European Study of the Epidemiology of Mental Disorders (ESEMeD) Project, 2004. Sampling and methods of the European Study of the Epidemiology of Mental Disorders (ESEMeD) project. Acta Psychiatr. Scand. 420 (Suppl), 8-20.

APA, 1994. Diagnostic and Statistical Manual of Mental Disorder, 4th edn. American Psychiatric Association, Washington, DC.

Baca-García, E., Vaquero, C., Díaz-Sastre, C., Ceverino, A., Saiz-Ruiz, J., Fernández-Piquera, J., de Leon, J., 2003. A pilot study on a gene-hormone interaction in female suicide attempts. Eur. Arch. Psychiatry Clin. Neurosc. 253, 281-285.

Bernal, M., Haro, J.M., Bernert, S., Brugha, T., de Graaf, R., Bruffaerts, R., Lépine, J.P., deGirolamo, G., Vilagut, G., Gasquet, I., Torres, J.V., Kovess, V., Heide, D., Neeleman, J., Kessler, R., Alonso, J., ESEMED/MHEDEA Investigators, 2007. Risk factors for suicidality in Europe: results from the ESEMED study. J. Affect. Disord. 101, 27-34.

Cohen, L.S., 2003. Gender-specific considerations in the treatment of mood disorders in women across the life cycle. J. Clin. Psychiatry 64, 18-28.

Fairweather, A., Anstey, K.J., Rodgers, B., Jorm, A.F., Christensen, H., 2007. Age and gender differences among Australian suicide ideators. Prevalence and correlates. J. of Nerv. Ment. Dis. 195, 130-136.

Freeman, E.W., Sammel, M.D., Liu, L., Gracia, C.R., Nelson, D.B., Hollander, L., 2004. Hormones and menopausal status as predictors of depression in women in transition to menopause. Arch. Gen. Psychiatry 61, 62-70.

Genazzani, A.R., Bernardi, F., Pluchino, N., Begliuomini, S., Lenzi, E., Casarosa, E., Luisi, M., 2005. Endocrinology of menopausal transition and its brain implications. CNS Spectr. 10, 449-457.

Halbreich, U., Rojansky, N., Palter, S., Tworek, H., Hissin, P., Wang, K., 1999. Estrogen augments serotonergic activity in postmenopausal women. Biol. Psychiatry 37, 34-41.

Kessler, R.C., Ustun, T.B., 2004. The World Mental Health (WMH) survey initiative version of the World Health Organization (WHO) Composite International Diagnostic Interview (CIDI). Int. J. Methods Psychiatr. Res. 13, 93-121.

Mann, J.J., 1998. The neurobiology of suicide. Nat. Med. 4, 25-30.

Prior, J.C., 1998. Perimenopause: The complex endocrinology of the menopausal transition. Endocr. Rev. 19, 397-428.

Saunders, K.E., Hawton, K., 2006. Suicidal behaviour and the menstrual cycle. Psychol. Med. 36, 901-912.

Soares, C.N., 2008. Reproductive hormone sensitivity and risk for depression across the female life cycle: a continuum of vulnerability? J. Psychiatry Neurosci. 33 (4), 331-143. 